\title{
O casamento da histérica com o obsessivo
}

The obsessional-hysteric marriage

El casamiento de la histérica con el obsesivo

Francisco Paes Barreto*

\section{As estruturas clínicas}

A clínica lacaniana organizou-se em três estruturas que se constituíram a partir do legado freudiano: neurose, perversão e psicose. O que fundamenta a distinção é a operação estruturante específica de cada uma. No caso da neurose, foi bem definida por Freud: o recalque (Verdrängung). Um dos méritos de Lacan foi o de reconhecer a operação própria da psicose, a forclusão (Verwerfung), bem como a da perversão, o desmentido (Verleugnung). De que se trata em última análise?

Para expor a questão de forma sumária, é preciso trabalhar, pelo menos, três termos: sujeito, Outro e castração.

O que é o Outro, em Lacan? Numa primeira abordagem, o Outro é a estrutura da linguagem, é a cadeia significante, é a ordem simbólica que opera por mecanismos próprios (metáfora e metonímia). A linguagem diferencia radicalmente o reino humano do reino animal. Mais que diferenciar, o ingresso na linguagem marcou uma ruptura entre o universo humano e o universo animal. O humano tornou-se, por excelência, universo do discurso, em que se incluem as expressões sociais e culturais. O Outro, ou a ordem simbólica, ou a ordem da linguagem, por conseguinte, é a matriz do que é genuinamente humano.

Ao Outro a psicanálise opõe o Sujeito. Se o Outro é ordem, é matriz, é estrutura, o Sujeito é único, é efeito, é singularidade. O Outro ou a ordem simbólica antecede o Sujeito. Ou seja: antes de o Sujeito nascer, condicionado por um corpo biológico, o Outro já estava aí. Da mesma forma, o Outro persiste depois que o Sujeito deixa de existir. Ou quando se restringe a um nome, anunciado por "aqui jaz".

Roteiro da palestra proferida na Faculdade de Psicologia da PUC-MG, no dia 23 de setembro de 2011, a convite da Prof.a Ilka Franco Ferrari e da Prof. ${ }^{a}$ Lúcia Mello.

Analista membro (A. M. E.) da Escola Brasileira de Psicanálise e da Associação Mundial de Psicanálise. 
Para a psicanálise, a constituição do Sujeito é algo complexo, que começa, na melhor das hipóteses, pelo desejo dos pais. Mais adiante, ficará também a cargo dos pais a mediação, para o filho, do que diz respeito à ordem simbólica: pode-se, então, falar de Outro paterno ou de Outro materno. Muito se enfatiza, nos dias de hoje, a hereditariedade ou herança, mas esses termos ficam reduzidos ao que é da ordem da Biologia, ou da Genética. A psicanálise, porém, leva em consideração a herança simbólica. Algo que passa dos pais para os filhos, mas em outro nível. Qual seria a essência dessa herança simbólica? Dizendo rapidamente algo que não é simples, trata-se de um significante que é capaz de organizar o mundo do Sujeito e de representá-lo. Representá-lo para quem? Para o Outro.

Numa segunda abordagem, portanto, o Outro pode ser definido como a ordem simbólica tal como é apreendida pelo Sujeito. O Outro é o Outro do Sujeito, que pode encontrar várias encarnações possíveis: o pai, a mãe, o médico, o professor, o juiz, o delegado, o prefeito, o padre, etc., etc.

Disse, há pouco, que, na herança simbólica, há um significante-chave. Lacan designou-o como o significante do Nome-do-Pai. Fazendo um paralelo, eu diria que o Nome-do-Pai é o DNA da herança simbólica. Por outro lado, as três estruturas clínicas já mencionadas dependem exatamente das vicissitudes da herança simbólica, isto é, de como ocorreu a inscrição do significante do Nome-do-Pai.

O Nome-do-Pai é, exatamente, o significante que opera a castração. A inscrição do Nome-do-Pai no Outro do Sujeito é condição necessária para a inscrição da castração.

Lacan afirma que "O estado do sujeito $S$ (neurose ou psicose) depende do que se desenrola no Outro A” (Lacan, 1985).

Dizendo mais claramente de que se trata: na psicose, não há inscrição do Nome-do-Pai no Outro, ou o Outro não é castrado. Poderia ainda ser dito que o psicótico, inconscientemente, não admite a castração materna. $\mathrm{Na}$ psicose, o grande A não é barrado. $\mathrm{O}$ que se chama de forclusão, portanto, é a exclusão fundamental do significante paterno, e consequentemente, da inscrição da castração.

E na neurose? Nesse caso, há a inscrição do significante paterno no Outro do Sujeito, que se mostra barrado: A/. O neurótico, por conseguinte, tem registro da castração materna. É o que se passa no plano simbólico. No plano imaginário, porém, o neurótico acredita na completude do Outro, acredita na existência da proporção sexual e nega, desse modo, a castração. $\mathrm{O}$ resultado 
é uma vacilação entre A barrado e A não barrado, entre A e A/. Ou seja, enquanto na psicose há uma certeza, na neurose há uma vacilação.

E na perversão? Aqui existe a inscrição do significante paterno e da castração, mas, por outro lado, verifica-se a coexistência de duas posições diametralmente opostas. A castração é, ao mesmo tempo, admitida e negada. O perverso administra, sem conflito, a concepção do Outro barrado, A/, ao lado da concepção do Outro não barrado, A. É o que se chama de desmentido.

\begin{tabular}{lll}
\hline CLÍNICA LACANIANA & & \\
\hline $\begin{array}{l}\text { ESTRUTURAS } \\
\text { CLÍNICAS }\end{array}$ & OPERAÇÕES ESTRUTURANTES & $\begin{array}{l}\text { GRANDE } \\
\text { OUTRO }\end{array}$ \\
\hline Neurose & Recalque (Verdrängung) & A ou A/? \\
Perversão & Desmentido (Verleugnung) & A e A/ \\
Psicose & Forclusão (Verwerfung) & A \\
\hline
\end{tabular}

\section{A histérica e o obsessivo}

As três estruturas clínicas apresentam diferentes tipos clínicos. Para o que é do nosso interesse, hoje, ficarei restrito aos dois principais tipos clínicos de neurose: a histeria e a obsessão.

Darei, logo de início, duas minidefinições, com base no que foi colocado. Como foi dito, a neurose pode ser definida como vacilação entre A e A/ (Soler, 1993, p. 29), entre Outro castrado e não castrado, ou incompleto e completo, ou inconsistente e consistente. A histeria como tipo clínico, por sua vez, pode ser definida como fuga da vacilação pela exacerbação da falta, enquanto que a obsessão seria a fuga da vacilação pela obliteração da falta. É um começo de abordagem da nossa questão.

Com base nesses termos, o casamento da histérica com o obsessivo evoca o casamento da chave com a fechadura, que faz acreditar na existência da proporção entre os sexos, na complementação de um pelo outro. Eis aí o apelo imaginário que sustenta a união. Mas eis aí, também, o logro ou o engano que faz a tormenta do casal. Pois a ânsia de obturar do obsessivo só tem paralelo na ânsia de esburacar da histérica.

Como é que cada Sujeito trata o Outro? O sujeito da histeria é atraído pelo amor à figura do Mestre, pelo amor ao seu saber, tal como mariposa atraída pela lâmpada. Sua intenção, num primeiro momento, é a de reconhecê-lo, mas, num segundo momento, é a de destituí-lo, ou destruí-lo, ao apontar-lhe a falta. É a paciente que "prova” que o grande médico não consegue curá-la, é 
a aluna que descobre o que o sábio professor desconhece, é o infrator que dá um nó no policial famoso.

O sujeito da obsessão, por seu turno, visa de imediato à destruição do Outro na constituição de seu desejo. Trata-se de uma destruição articulada no nível do significante. Isso num primeiro momento. O problema é que a destruição do Outro, nesses termos, resulta na destruição do próprio Sujeito, pois se trata do Sujeito da fala. Como consequência, o obsessivo, num segundo momento, visa à restauração amorosa do Outro... O que era ódio se converte em servidão. Tudo para o Outro... Na tentativa de reparar o dano causado (Teixeira, 2010, p. 51-61).

Pode-se ver, por aí, que o Sujeito, da histérica, é o Outro, do obsessivo, e vice-versa. Razão pela qual o casamento da histérica com o obsessivo tem tudo para dar certo, e tudo para dar errado.

As coisas não ficam por aí. É preciso considerar, por exemplo, a questão do objeto, a questão do desejo.

Quanto a isso, qual a posição da histérica? Classicamente, ela se apresenta como sedutora, ou como objeto de desejo. Todavia há algo de particular nesse oferecimento; ela recua, ou se retrai, quando o conquistador se aproxima. Ela se mostra como objeto que se furta.

E qual a posição subjetiva do obsessivo em relação à questão do desejo? Para ele, o objeto de desejo é imaginariamente sustentado pela proibição do Outro. O suplício do obsessivo, então, é este: o desejo desaparece quando o objeto a ele se entrega.

Também quanto a esse aspecto podem ser captadas as bodas da histérica e do obsessivo.

Falei de amor. Em seguida, falei de desejo. Agora, falarei de gozo.

Quanto ao sujeito da histeria, é bem conhecida a fórmula segundo a qual a histérica tem desejo de desejo insatisfeito. Satisfazer o desejo é matar o desejo; sendo assim, insatisfazê-lo é elevá-lo à sua plenitude. Nada de gozo! A histérica quer desejar, a histérica não quer gozar.

E o obsessivo? Ora, se o obsessivo anula o Outro, ele destitui o parceiro como sujeito, ele o reduz à condição de objeto, objeto de seu gozo. A histérica ocupa a posição de objeto com facilidade, de objeto pequeno $a$, e, nesse aspecto, ela favorece a parceria amorosa com o obsessivo. Por outro lado, o encontro do desejo impossível de um com o desejo insatisfeito da outra é um complicador previsível. 
Para concluir, a parceria amorosa da histérica com o obsessivo é de tal ordem que os aspectos determinantes da aproximação são exatamente os mesmos que perturbam o casamento. Dizer que tem tudo para dar certo é tão procedente como afirmar que tem tudo para dar errado. Mais uma vez, não há regras, não há garantias e não há como se guiar por valores universais. As estruturas e os tipos clínicos são generalizações, são abordagens universalizadoras. Numa experiência psicanalítica, cada parceria, cada sujeito terá uma história e um desfecho que serão da ordem da singularidade, e não há estatística possível quando o caso é único.

\begin{tabular}{l|l}
\hline HISTERIA & \multicolumn{1}{l}{ OBSESSÃO } \\
\hline Fuga da vacilação pela exacerbação da falta & Fuga da vacilação pela obliteração da falta \\
\hline $\begin{array}{l}\text { O sujeito corteja o Mestre para, em seguida, } \\
\text { destituí-lo }\end{array}$ & $\begin{array}{l}\text { O sujeito destrói o Outro para, em seguida, } \\
\text { reconstituí-lo }\end{array}$ \\
\hline $\begin{array}{l}\text { Enquanto objeto de desejo, seduz e depois } \\
\text { se furta }\end{array}$ & $\begin{array}{l}\text { Quando o objeto se oferece, o desejo se } \\
\text { retrai }\end{array}$ \\
\hline A histérica quer desejar, não quer gozar & O obsessivo quer gozar, sem vigor de desejo \\
\hline O sintoma é metafórico: dois num só tempo & $\begin{array}{l}\text { O sintoma é metonímico: um em cada } \\
\text { tempo }\end{array}$ \\
\hline $\begin{array}{l}\text { Problematização do feminino: o que é uma } \\
\text { mulher? }\end{array}$ & $\begin{array}{l}\text { Problematização do masculino: o que é um } \\
\text { pai? }\end{array}$ \\
\hline O sujeito da histérica é o Outro do obsessivo & O sujeito do obsessivo é o Outro da histérica \\
\hline
\end{tabular}

\section{Fragmento clínico}

Sou procurado para análise por um senhor de 55 anos. O que trarei em seguida é uma montagem, uma reunião de diferentes momentos dessa experiência, à maneira de um pot-pourri.

- Sou de família paupérrima. Meu pai era carpinteiro e alcoólatra, minha mãe, lavadeira. Morávamos numa favela. A duras penas, consegui me formar num curso superior. Sou bem-sucedido na profissão, sou casado, tenho três filhos. Já fiz cinco anos de análise, que não resolveram nada. Decidi então mudar de analista. Tenho um unico problema na vida: sou totalmente frustrado na minha vida sexual, e isso perturba a minha vida como um todo.

- Como assim?

- Sou apaixonado por minha mulher, que, além do mais, desperta em mim uma grande atração sexual. Sou correspondido no meu amor; 
afinal somos casados há longos anos, não posso dizer que ela não gosta de mim. Mas, do ponto de vista estritamente sexual, minha vida é uma desgraça. Eu penso nela o dia inteiro, sonho com ela, masturbome com ela, e ela está do meu lado na cama, dorme comigo...

- Ela dorme com você?

- Literalmente. Não é que a gente não transe. A gente transa, sim. Mas é muito pouco. Quando a gente transa, é uma verdadeira maravilha. Eu durmo feliz, fico uma semana alegre, de tão bom que é.

— Então, você não é totalmente frustrado.

- Acontece que, de tão bom que é, eu fico querendo mais. E sabe o que acontece? Passa uma semana, nada. Passam duas semanas, nada. As vezes, chega a passar um mês! Demora tanto que algumas vezes, quando ela cedeu, eu brochei. E não adianta eu insistir, porque senão dá briga e até ameaça de separação. Eu tenho de ficar quieto no meu canto, aguardando o sinal.

- Sinal?

- É... a gente percebe quando ela quer.. depois de tanto tempo juntos... são pequenos sinais de receptividade...

- Ém casamento e tanto.

- De maneira alguma. O senhor diz isso porque não avalia corretamente o meu sofrimento. Sou muito aceso, sexualmente. É tão dificil suportar a longa abstinência que uma colega de trabalho, a quem confessei meu drama, sugeriu-me pular a cerca. Durante muito tempo, pensei nisso, bolei mil planos, mas nada foi pra frente.

- Não é a mesma coisa.

- Não, não é. E tem mais: suspeitei que a minha colega de trabalho disse isso porque gostaria que eu pulasse a cerca... com ela. Ela é casada, mas não é castrada... Eu é que me sinto assim: casado e castrado.

- Mas... O que você faz, para namorar a sua mulher?

- O que eu faço? Como assim? Afinal, já somos casados! E o que é pior: há tantos e tantos anos, que nem sei se ainda dá tempo de recomeçar. 
- Tempo de reconquistá-la.

— Não, não há mais tempo.

- Nunca é tarde.

\section{Referências}

LACAN, J. (1985). O Seminário: livro 3: as psicoses. (1955-1956). Rio de Janeiro: Jorge Zahar.

Soler, C. (1993). Fines del analisis. Historia y teoria. In: Finales de Analisis. (p. 29). Buenos Aires: Manantial.

Teixeira, A. M. R. (2010, janeiro/julho). As bodas sintomáticas do obsessivo com a histérica. In: Agora: estudos em Teoria Psicanalítica, 13 (1), 51-61. 